\title{
Spatial variability of stable isotope ratios in oysters (Crassostrea gigas) and primary producers along an estuarine gradient (Bay of Brest, France)
}

Violette Marchais ${ }^{\mathrm{a}}$, Gauthier Schaal ${ }^{\mathrm{a}}$, Jacques Grall ${ }^{\mathrm{a}}$, Anne Lorrain ${ }^{\mathrm{a}}$, Caroline Nerot $^{\mathrm{a}}$, Pierre Richard ${ }^{\mathrm{b}}$, Laurent Chauvaud ${ }^{\mathrm{a}}$.

aUMR 6539, LEMAR, Institut Universitaire Européen de la Mer, place Nicolas Copernic, 29280 Plouzané, France

bUMR 6250, LIENSs, Université de la Rochelle, Bât. Marie Curie, rue Paul-Emile Victor, 17000 La Rochelle, France

Corresponding author:

Violette Marchais

Email: violette.marchais@univ-brest.fr

Tel.: +33298498660

Fax.: +33298498645

\begin{abstract}
This study aimed at characterizing the diet of the oyster Crassostrea gigas along an estuarine gradient in the Bay of Brest (France), through stable isotope $\left(\delta^{13} \mathrm{C}\right.$ and $\left.\delta^{15} \mathrm{~N}\right)$ measurements in primary producers and wild oysters. The contribution of different potential food sources to the diet of $C$. gigas was estimated at high spatial resolution (over a gradient of $40 \mathrm{~km}$ with samplings every $2 \mathrm{~km}$ ) to identify ecological transition zones, and highlighted the dominance of resuspended biofilm in oysters diet. Although the different primary producers did not display any obvious pattern along the estuarine gradient, the stable isotope signatures of $C$. gigas differed among estuarine, inner Bay and open sea sites. In particular, a striking ${ }^{15} \mathrm{~N}$ depletion pattern was found along the gradient which allowed to identify seven homogeneous groups. Moreover, some unexpected values found at two stations within the estuary revealed localized anthropogenic disturbances. Overall, our results suggest that suspension-feeders might be better indicators of ecosystem functioning than primary producers, and reflect the different ecological processes occurring along estuarine gradients, including localized anthropogenic inputs. We suggest that the usefulness of suspension-feeders as indicators of ecosystem functional typology lies in the dominance of benthic material in their diet, which results in locally occurring processes being reflected in oysters' stable isotope ratios.
\end{abstract}

KEY WORDS: biofilm - carbon - nitrogen - food web - estuary - Bay of Brest 


\section{Introduction}

Coastal environments are extremely productive ecosystems that receive nutrients of both terrestrial and marine origin, and host high animal biomasses (Mann 1982). The use of coastal benthic invertebrates to infer different aspects of ecosystem functioning has been developed recently (Deegan and Garritt 1997; Lefebvre et al. 2009a). In particular, suspension-feeders are usually considered as good indicators of ecosystem functioning (Lefebvre et al. 2009a), because as primary consumers, they directly reflect ecological processes occurring at the lowest levels of food webs.

Several authors have used stable isotopes $\left(\delta^{13} \mathrm{C}\right.$ and $\left.\delta^{15} \mathrm{~N}\right)$ in suspension-feeders as markers of ecological processes occurring along estuarine gradients (Hughes and Sherr 1983; Riera and Richard 1996; Deegan and Garritt 1997). Because stable isotopes usually strongly differ among primary producers of freshwater, estuarine and marine origin (Currin et al. 1995), and are time-integrated markers in macroinvertebrates, they allow to track the relative influence of different sources to the diet of suspension-feeders. $\delta^{13} \mathrm{C}$ is typically variable among different primary producers, and is therefore often used as an indicator of basal food sources (Riera and Richard 1996), whereas $\delta^{15} \mathrm{~N}$ is usually indicative of consumers trophic level (Post 2002), but can also be used to infer food sources assimilated by primary consumers (Riera 1998). Moreover, anthropogenic activities along the coast and in catchments often result in ${ }^{15} \mathrm{~N}$ enriched stable isotope ratios in producers and consumers (Costanzo et al. 2001). $\delta^{15} \mathrm{~N}$ can therefore also be used as a marker of anthropogenic influence on natural communities.

The Pacific oyster, Crassostrea gigas, has been introduced in France in the 1970s for aquaculture (Mann 1982), and is now a common component of rocky shore communities along the coastline of Brittany (Lejart 2009). Previous stable isotope studies have shown that this species is a good tracer of temporal and spatial variations of organic matter sources (Malet 2005; Lefebvre et al. 2009a). In particular, C. gigas has been used to infer spatial variability occurring in the trophic functioning of estuarine systems (Riera and Richard 1996; Riera et al. 2000; Lefebvre et al. 2009a). For instance, the contribution of terrestrial material to the diet of oysters inhabiting upper estuarine zones of the Charente river estuary (French Atlantic coast) has been highlighted by Riera and Richard (1996). High anthropogenic inputs on estuarine food webs have also been reported to result in ${ }^{15} \mathrm{~N}$-enriched stable isotope ratios in the community inhabiting the Westerschelde (Netherlands) (Riera et al. 2000). Lefebvre et al. (2009a) concluded that oysters could be used as indicators of coastal typology, due to the plasticity of their diet (Riera 2009) and their capacity to withstand highly variable environmental conditions (Le Berre et al. 2009). Moreover, suspension-feeders stable isotope ratios display a relative temporal stability (muscle $\delta^{13} \mathrm{C}$ and $\delta^{15} \mathrm{~N}$ varied seasonally of 1\%o (Lorrain et al. 2002) in the bay of Brest, although higher variability (up to 3\%) has been observed for other ecosystems (Fertig et al. 2010)), which is an advantage compared to particulate organic matter (POM)-based indicators, which can experience highly chaotic variability (values differed by more than 6 \% (Savoye 2001)). However, in order to fully understand ecological transitions occurring along estuarine gradients, studies involving high resolution sampling are necessary. Up to now, these studies are quite scarce (Fertig et al. 2009), there is therefore a need for such studies to assess the usefulness of suspension-feeders as natural markers for functional ecosystem typology (sensu Lefebvre et al. 2009a).

This study aimed to determine the diet of the oyster Crassostrea gigas at high spatial resolution along a $40 \mathrm{~km}$ gradient in an estuarine bay (Bay of Brest, France). To identify the functional transition zones as well as the extent of terrestrial (including anthropogenic) influence, we measured stable isotope values of the intertidal suspension feeder Crassostrea gigas, together with the stable isotope ratios of the potential food sources (suspended particular organic matter, biofilm and macroalgae) along an estuarine gradient from upstream to marine conditions. The objectives of this study were to evaluate along this gradient (i) the relative contributions of benthic vs. pelagic sources, (ii) terrestrial vs. marine 
influences on this semi-enclosed ecosystem and (iii) the ability of stable isotopes to reveal potentially localized anthropogenic inputs to coastal environments.

\section{Material and methods}

\subsection{Sampling sites}

The Bay of Brest (Brittany, France) is a shallow semi-enclosed $180 \mathrm{~km}^{2}$ embayment connected to oceanic water (Iroise Sea) by a narrow (1.8 km of wide) and deep (40 m) channel (Le Pape 1996). Strong tidal currents (5 knots in the channel and $21 / 2$ knots inside the Bay) allow exchange of waters between the Bay and the Iroise sea. 40\% of the bay is renewed at each tide cycle through the channel (Le Pape et al. 1996). The shallowness of the bay and the water mixing induced by tidal currents prevent the ecosystem from vertical stratification and nutrient accumulation, and therefore limit eutrophication of the system (Le Pape et al. 1996). Nutrients input from the Elorn river are nevertheless important, and have been estimated of $550 \mu \mathrm{mol} . \mathrm{L}^{-1}$.year ${ }^{-1}$ on average since the early 2000s (Bretagne environnement 2009). In the intertidal zone, substrates are dominated by rocky shore whereas sediments in subtidal zone range from muds to coarse gravel and maerl beds depending on local hydrodynamics conditions (Grall et al. 1996).

\subsection{Sampling}

Sampling was performed at 19 stations along an estuarine gradient, from the Elorn river estuary down to Le Conquet (Fig. 1) in November 2009 at low tide. At each station, 5 living adult oysters (Crassostrea gigas) (size ranging from 50 to $100 \mathrm{~mm}$ ) were collected around low tide in the mediolittoral zone and frozen $\left(-20^{\circ} \mathrm{C}\right)$ until dissection. Adductor muscles were then dissected and frozen until further processing.

The most abundant macroalgae (Fucus spp., Ascophyllum nodosum, Himanthalia elongata, Bifurcaria bifurcata, Ulva spp., Vertebrata lanosa, Mastocarpus stellatus, Osmundea pinnatifida, Chondrus crispus, Palmaria palmata, Calliblepharis jubata, Lomentaria articulata, Dilsea carnosa, Gelidium sp.) were also collected for stable isotope analysis. Their apex part was briefly washed with distilled water to remove epiphytes, and they were stored frozen $\left(-20^{\circ} \mathrm{C}\right)$ until further processing. For Suspended Particulate Organic Matter (SPOM) sampling, water samples were also collected at each station, prefiltered on $63 \mu \mathrm{m}$ to remove zooplankton and large particles, and then filtered (volume depending on particle concentration) on precombusted $\left(450^{\circ} \mathrm{C}\right.$, $\left.4 \mathrm{~h}\right) \mathrm{GF} / \mathrm{F}$ filters. Biofilm was sampled by gently brushing the rocks with a toothbrush, which was then resuspended in filtered $(0.7 \mu \mathrm{m})$ seawater. This operation is renewed several times for each station. Water containing biofilm was then filtered following the SPOM protocol.

A total of 89 oysters, as well as 46 SPOM, 19 biofilm and 83 macroalgae samples were analyzed for $\delta^{13} \mathrm{C}$ and $\delta^{15} \mathrm{~N}$ during this study (see table in electronic supplementary material with values of oysters and sources at each station).

\subsection{Isotopic analysis}


Oyster muscles and macroalgae were freeze dried and ground into powder. 300 $\mu$ g (oysters) and $1 \mathrm{mg}$ (macroalgae) were then weighed in tin capsules. Biofilm and SPOM filters were dried $\left(60^{\circ} \mathrm{C}, 12 \mathrm{~h}\right)$, decarbonated 4 hours with $\mathrm{HCl}$ vapors (Lorrain et al. 2003) and dried again overnight. The colored matter of filters (SPOM and biofilm) was then scraped with a clean scalpel and introduced in tin cups.

Samples were analyzed using an elemental analyzer (Flash EA 1112, Thermo Scientific, Milan, Italy) coupled to an isotope ratio mass spectrometer (Delta V Advantage with a Conflo IV interface, Thermo Scientific, Bremen, Germany). Results are expressed in the $\delta$ unit notation as deviations from standards (Vienna Pee Dee Belemnite for $\delta^{13} \mathrm{C}$ and $\mathrm{N}_{2}$ in air for $\delta^{15} \mathrm{~N}$ ) following the formula: $\delta^{13} \mathrm{C}$ or $\delta^{15} \mathrm{~N}=\left[\left(R_{\text {sample }} R_{\text {standard }}\right)-1\right]$ x $10^{3}$, where $R$ is ${ }^{13} \mathrm{C} /{ }^{12} \mathrm{C}$ or ${ }^{15} \mathrm{~N} /{ }^{14} \mathrm{~N}$. Reference gas calibration was done using reference materials (USGS-24, IAEA-CH6, IAEA-600 for carbon ; IAEA-N1, -N2, -N3, -600 for nitrogen). Analytical precision based on isotope values of the acetanilide (Thermo Scientific) used to estimate $\mathrm{C}$ and $\mathrm{N}$ content for each sample series was $<0.1 \%$ both for carbon and nitrogen. Values are mean \pm s.d.

\subsection{Data analysis}

All statistical analysis were performed under the R software (R development Core Team 2005).

Normal distribution of data and homogeneity of variances were checked using Shapiro-Wilk tests and Bartlett-tests. When these tests were non-significant, one factor ANOVAs were conducted (One-way test if the homoscedasticity is invalid). Otherwise, Kruskal-Wallis tests were used. If differences were highlighted, a pairwise test was conducted with Holm method.

A hierarchical clustering was realized on $\delta^{13} \mathrm{C}$ and $\delta^{15} \mathrm{~N}$ of oyster muscles, using Euclidean dissimilarity and Ward's minimum variance method. Obtained groups significance had been tested by an analysis of similarity (ANOSIM) with Euclidean distances.

The composition of SPOM at each site, as well as the contribution of the different food sources to the diet of C. gigas was estimated using SIAR (Stable Isotope Analysis with R (Parnell et al. 2010)) using Bayesian inference. This model is the currently considered as more relevant than traditional linear mixing models (e.g. Isosource, (Phillips and Gregg 2003)) to characterize the diet of consumers, because it incorporates the variability in the stable isotope ratios of both sources and consumers, as well as in the isotopic fractionation (Parnell et al. 2010). For SIAR modeling, we considered different isotopic fractionations, to cope with the inherent variability of this factor: 1) the isotopic fractionation determined by Dubois et al (2007a) for the whole body of Crassostrea gigas $\left(\Delta \delta^{13} \mathrm{C}=1.9 \pm 0.2 \%\right.$ and $\Delta \delta^{15} \mathrm{~N}=3.8 \pm$ $0.2 \%$ ), 2) the fractionation from Lefebvre et al. (2009a) $\left(\Delta \delta^{13} \mathrm{C}=2.9 \pm 0.5 \%\right.$ and $\Delta \delta^{15} \mathrm{~N}=4.7 \pm 0.5 \%$ ) and 3) the fractionation of Dubois et al. (2007a) corrected by the muscle-to-whole body factor of Yokoyama et al. (2008) $\left(\Delta \delta^{13} \mathrm{C}=\right.$ $2.3 \pm 0.2 \%$ and $\Delta \delta^{15} \mathrm{~N}=7.1 \pm 0.2 \%$ ). Because SPOM sampled at each station is a heterogeneous pool that already includes terrestrial POM, marine phytoplakton, macroalgae detritus en resuspended benthic biofilm, it has not been considered as a potential contributor when modeling the diet of $C$. gigas. We considered only pure food sources: benthic biofilm and macroalgae that were collected on each site, as well as terrestrial POM (TPOM) and marine POM (MPOM). Macroalgae were regarded as the average of the stable isotope ratios measured for the 3 to 7 dominant species (see table in suppl. material). TPOM was considered as the average of measurements carried out in 2008 and 2009 (Nérot 2011) in Landerneau, which is the upper limit of tides influence in the Elorn river $\left(\delta^{13} \mathrm{C}=-27.5 \pm 1.2 \%\right.$; $\delta^{15} \mathrm{~N}=5.9 \pm 2.0 \%$ o). MPOM was considered as the average of different measurements carried out in 2008 and 2009 in the Iroise Sea, that displayed $\mathrm{C} / \mathrm{N}$ ratios comprised between 6 and 8, indicative of phytoplankton dominance (Savoye 2001) $\left(\delta^{13} \mathrm{C}=-23.1 \pm 0.9 \% ; \delta^{15} \mathrm{~N}=5.7 \pm 1.1 \%\right)$. 


\section{Results}

\subsection{Isotopic ratios of oyster muscles}

Along the gradient, the $\delta^{13} \mathrm{C}$ of oysters ranged from -18.2\%o (station 6) to -17\%o (station 12) (Fig.2). Although no significant pattern could be highlighted, estuarine and open-sea sites displayed values around $-17.5 \%$, while inner bay sites were slightly ${ }^{13} \mathrm{C}$ enriched, around $-17 \%$. Two estuarine stations (5 and 6 ) displayed the lowest $\delta^{13} \mathrm{C}$, below $-18 \%$. For $\delta^{15} \mathrm{~N}$, a decreasing pattern was observed along the gradient, from values around 12 \% in the upstream estuary, down to less than $10 \%$ at le Conquet (station 19). The hierarchical clustering performed on the stable isotope ratios of oysters identified 2 main groups (Fig. 3), that corresponded to estuarine (stations 1 to 9) and open sea stations (stations 10 to 19). Seven significant (ANOSIM, R=0.998, p-value<0.001) sub-groups could also be identified: upstream estuary, middle estuary, downstream estuary, inner bay, channel, outside bay, and station 18. Sampling stations were aggregated according to this grouping for further analysis. The $\delta^{15} \mathrm{~N}$ of oysters was significantly correlated to biofilm's $\delta^{15} \mathrm{~N}$ $\left(R^{2}=0.73 ; \mathrm{p}<0.01\right)$ (table 1). This was not the case, however, for $\delta^{13} \mathrm{C}$, nor for any of the other sources (neither for $\delta^{13} \mathrm{C}$ nor for $\delta^{15} \mathrm{~N}$ ) (see table 1$)$.

\subsection{Isotopic ratios of food sources}

In spite of high variability along the gradient, no decreasing or increasing trend could be identified in the stable isotope ratios of SPOM (Fig. 4). No statistically significant difference was found for $\delta^{15} \mathrm{~N}$ (between $6.8 \%$ and $7.7 \%$ ) (table 2), and although some differences were observed for $\delta^{13} \mathrm{C}$ (see table 2), they were mostly due to middle estuary stations (i.e. stations 5 and 6), that displayed ${ }^{13} \mathrm{C}$ enriched values. Upstream sites were slightly ${ }^{13} \mathrm{C}$ depleted compared to other sites (-23.1 \% compared to $\delta^{13} \mathrm{C}$ ranging from -22.3 \% to -20.5 \%o for other groups). Biofilm $\delta^{13} \mathrm{C}$ did not vary significantly (ranging from -21.9 \%о to $-18.6 \%$ with strong intra-zone variability). Besides, a clear ${ }^{15} \mathrm{~N}$ depletion gradient was observed along the gradient, with values close to $9 \%$ in the upstream estuary, and close to $6 \%$ outside the bay (see table 2 and Fig. 4). For macroalgae as well, no trend could be highlighted along the estuarine gradient, neither for $\delta^{13} \mathrm{C}$ nor for $\delta^{15} \mathrm{~N}$.

\subsection{Contribution of each food source}

All along the gradient, benthic biofilm was the dominant contributor to the diet of C. gigas (Fig. 5), it average contribution ranging from $47 \%$ to $85 \%$. In the middle estuary, the diet of oysters was more balanced, biofilm, MPOM and macroalgae displaying quite similar contributions. The contribution of macroalgae ranged from $9 \%$ (channel) to 33\% (upper estuary) and MPOM contributed between 4\% and 35\%. The contribution of TPOM was negligible all along the gradient, even for upper estuary sites.

The sensibility analysis showed little variation among the different fractionation factors considered (table 3). The contribution of biofilm was always higher than 40\%, and the contribution of TPOM stayed negligible. Most of the variability induced by the different factors considered concerned macroalgae and MPOM contribution in the estuarine area. The importance of MPOM was higher for this area considering the factors of Lefebvre et al. (2009a), while macroalgae were estimated to contribute more the diet of C. gigas using the factors of Dubois et al. (2007a) corrected by Yokoyama et al. (2008).

\section{Discussion}




\subsection{Primary producers}

Most of stable isotope ratios measured on primary producers in this study fell into the range commonly reported for SPOM, macroalgae and biofilm along the French Atlantic coast (Riera and Richard 1996; Schaal et al. 2010b). Surprisingly, none of the sources sampled reflected the commonly observed ${ }^{13} \mathrm{C}$ enrichment pattern along the estuarine gradient. Due to the predominance of ${ }^{13} \mathrm{C}$ depleted C3 plants in catchments, freshwater and upstream estuary primary producers usually display low $\delta^{13} \mathrm{C}$ values (Peterson and Fry 1987). Although measurement carried out upstream the Elorn river showed characteristic $\delta^{13} \mathrm{C}(-27.5 .3 \pm 1.2 \%$, (Nérot 2011)), this was not observed in other sampling stations of the estuary. For upper-estuary sites, TPOM contribution to the SPOM reached 22\% (see suppl. material), but was already negligible at mid-estuary sites and all along the gradient. Tidal flushing (40\% of the Bay is renewed at each tidal cycle (Le Pape et al. 1996)) is likely to play an important role in the immediate dilution of ${ }^{13} \mathrm{C}$ depleted freshwater in the estuary, hence limiting the effects of terrestrial nutrients and pollutants brought to the estuary and the bay by rivers. Similar results were reported by York et al. (2007). They suggested that phytoplankton that acquired its isotopic signature upstream maintained it while its downstream transport, thereby masking any isotopic gradient along estuaries. This explanation is however unlikely to be relevant to the Elorn river estuarine system, because the stable isotope ratios measured for phytoplankton are not characteristic of upper estuarine systems and the tidal flow results in strong mixing of waters in the estuary during high tide. The absence of estuarine signal in macroalgae, neither for carbon nor for nitrogen, seems to contradict some studies that found that macroalgae were good indicators of anthropogenic inputs (Costanzo et al. 2001) and could also be explained by the importance of tidal flow. Fertig et al. (2009) found that stable isotopes in macroalgae failed to identify fine scale pattern, which supports our finding. Contrarily to other food sources, biofilm displayed a marked ${ }^{15} \mathrm{~N}$ depletion pattern along the estuarine gradient. $\delta^{15} \mathrm{~N}$ of biofilm values in the estuary were similar to those measured by Costanzo el al. (2001) probably indicating some influence of wastewater originating from human activities ( $\delta^{15} \mathrm{~N}$ between 7 and $9 \%$ ). The same values (around $8 \%$ ) have been reported for epilithic biofilm within the harbour of Brest, on a site strongly impacted by human-derived inputs (Schaal et al. 2010b). The catchment of the Elorn river is characterised by intensive pig, cattle and poultry farming, as well as vegetables production (Grall and Glémarec 1997), that produces wastes that are transferred to coastal ecosystems through riverine discharge. Yet, out of the three primary producers sampled, only epilithic benthic biofilms reflected the typical ${ }^{15} \mathrm{~N}$ depletion pattern along the estuary. Although some resuspension occurs with upcoming flow (Takai et al. 2004), benthic biofilms are not entirely exported, contrarily to suspended POM (SPOM), that is almost entirely renewed at each tide cycle. Hence, benthic biofilms are more likely to integrate terrestrial nutrients brought from the catchment by rivers. Moreover, because biofilms are mainly constituted of unicellular organisms (i.e. bacteria, diatoms), their turnover is likely to be higher than macroalgae. Riverine inputs are typically episodic, depending on rain events. We can therefore hypothesize that the absence of terrestrial signal in macroalgae is due to the fact that they integrate nutrients over a time scale that buffers the effects of episodic nutrient pulses on their stable isotope ratios. The absence of clear $\delta^{13} \mathrm{C}$ pattern in any source is surprising, because ${ }^{15} \mathrm{~N}$ depletion pattern observed in benthic biofilms suggests that riverine inputs are assimilated in benthic primary producers. The amount of nitrates brought to the Bay of Brest by the Elorn river is extremely high (around $550 \mu \mathrm{mol} . \mathrm{L}^{-1}$.year ${ }^{-1}$, Bretagne Environnement 2009). In comparison, larger rivers, such as the Potomac river (USA) or the Zaire river (Democratic Republic of Congo) release respectively $110 \mu \mathrm{mol}^{-L^{-1}}$.year ${ }^{-1}$ and 8 $\mu \mathrm{mol} . \mathrm{L}^{-1}$.year ${ }^{-1}$ to their nearby coastal environment (Rajagopal 1997). Consequently, although to global freshwater inflow to the Bay of Brest is low $\left(176.10^{6} \mathrm{~m}^{3} \cdot \mathrm{y}^{-1}\right)$, it is still affecting primary producers $\delta^{15} \mathrm{~N}$. In contrast, lower dissolved inorganic carbon concentrations brought by the river do not result in significant $\delta^{13} \mathrm{C}$ pattern. Stable isotope 
measurements carried out on dissolved organic matter would help answer this question. Overall, these results suggest that, among co-occurring estuarine primary producers, epilithic benthic biofilms are the best indicators of terrestrial inputs in the Bay of Brest.

\subsection{Composition of Crassostrea gigas diet}

Isotopic ratios measured for oysters were consistent with previous studies carried out on estuarine systems along the French Atlantic coast (Riera and Richard 1996; Riera 1998; Lefebvre et al. 2009a). Similarly to what was observed for the different primary producers, the typical ${ }^{13} \mathrm{C}$ enrichment gradient was not found in Crassostrea gigas (Fig.4), supporting the finding that particulate organic matter inputs from the Elorn river have a low influence on benthic organisms inhabiting the Bay of Brest. Although the $\delta^{13} \mathrm{C}$ variability was quite low along the gradient (excepted for stations 5 and 6, see below), 7 different groups could be identified which can be aggregated into 2 geographic zones (estuary and open sea). For $\delta^{15} \mathrm{~N}$, a striking ${ }^{15} \mathrm{~N}$ depletion pattern was found along the gradient that correlated with the pattern observed for benthic biofilms (table 1). Overall, although none of the food sources allowed the identification of the different hydrographic bodies (excepted for biofilm $\delta^{15} \mathrm{~N}$ which differed among the 7 groups), the stable isotope ratios measured in oysters did so (Fig. 2). This necessarily raises some questions about the nature of the food assimilated by oysters. Oysters feed within a composite pool of organic suspended material, and have been observed in previous studies to assimilate extremely variable dietary sources (Riera and Richard 1996; Schaal et al. 2008; Lefebvre et al. 2009b). The use of isotopic mixing models is extremely sensitive to the choice of end-members (Phillips and Gregg 2003). In the case of suspension-feeders, although a wide array of food items has been reported to contribute to their diet, they first need to be transferred to the water column to become physically available to these consumers. Hence, SPOM samples collected on the different study sites are already constituted of a mix of all different "pure" food sources, and should not be considered as end-members. Here, four potential food sources were considered for SIAR calculations: epilithic benthic biofilms, macroalgae (regarded as the average of locally dominant macroalgae), marine POM (assimilated to pure marine phytoplankton) and terrestrial POM (isotopic signature measured at the upper limit of tidal influence in the Elorn river).

Reliable use of isotopic mixing models requires accurate trophic-step fractionation factors which are unfortunately rarely available for marine consumers. This fractionation is likely to vary according to the tissue analyzed, the environment considered or the age of the specimen (Vander Zanden and Rasmussen 2001; McCutchan et al. 2003). Here, we used various factors from the literature to estimate the variability induced in the diet estimation by this uncertainty. A low variability was observed among the different fractionation considered, benthic biofilm remained the most important contributor to the diet of C. gigas (table 3). The diet of oysters in the upper estuarine zone differed considering the fractionation of Dubois et al. (2007a) modified according to Yokoyama et al. (2008), through a dominant contribution of macroalgae. Fractionation factors from Lefebvre et al. (2009a) increased the contribution of MPOM, but only for estuarine stations, which is quite unlikely, because phytoplankton is supposed to less available to suspension-feeders in this area than in open sea stations. For other zones, the different fractionations yielded similar results, which support the robustness of our estimations. Consequently, the rest of the analysis is based on Dubois et al. (2007a) factors, which do not significantly differ from those corrected by Yokoyama et al. (2008), and are more likely, for this particular system, than those from Lefebvre et al. (2009a). 
Previous studies investigating the diet of Crassostrea gigas found that SPOM and/or epipelic benthic biofilms were predominant, their respective contributions depending on the location and/or the season of sampling (Riera and Richard 1996; Kang et al. 1999; Page and Lastra 2003; Piola et al. 2006; Marin-Leal et al. 2008). Surprisingly, in our study, marine SPOM did not contribute significantly to the diet of oysters in any of the 19 stations sampled (Fig. 5). The predominance of benthic biofilms in the diet of C. gigas, already suggested by the correlation between biofilms and oysters stable isotope ratios (table 1), was largely confirmed by SIAR modeling. This is in accordance with the findings of Takai et al. (2004), who concluded that epilithic biofilm was an important trophic resource for wild oysters, due to the importance of epilithic biofilm resuspension with incoming tide flow. Microphytobenthos, which constitutes an important part of benthic biofilms, has long been known to be important for oysters production (Riera and Richard 1996; Dubois et al. 2007b). On rocky shores, benthic biofilms can be dominated by diatoms, and also include bacteria and algal spores embedded in a matrix of extracellular substance (Hawkins et al. 1989). Once resuspended, all these components can easily be assimilated by suspension-feeders, which make benthic biofilms a highly nutritive food source. The results of this study are in apparent contradiction with the conclusions of a previous study carried out by Alunno-Bruscia et al. (2011). These authors found that the annual growth of C. gigas matched the seasonal variability of phytoplankton biomass in the bay, and concluded that they primarily relied on this source for diet. However, in this study, the sources were not identified, and we can therefore hypothesize that benthic diatoms follow the same seasonal trend as phytoplankton, because the same factors (i.e. temperature, light, nutrients) drive their productivity. Consequently, oysters assimilating a mix of phytoplankton and microphytobenthos would display the same seasonal pattern as oysters feeding on phytoplankton. Another explanation that could explain the differences between the conclusions of Alunno-Bruscia et al. (2011) and ours is based on the accurate localization of sampling areas within the bay. While our study took place in the northern basin, where hydrodynamics is quite important, the study of AlunnoBruscia et al. (2011) was carried out on cultivated oysters sampled in the southern basin, where hydrodynamics is more reduced, and resuspension events probably less important.

Apart from the large dominance of benthic biofilms to the diet of $C$. gigas, macroalgae appeared to be a non negligible component of oysters diet, in particular in upstream and middle estuary. Although remaining secondary dietary items, macroalgae can represent up to $30 \%$ of the diet of oysters in upper and mid-estuary, where the highest biomasses of algae observed (personal observations). These estimations are quite similar with the ones reported by Marin Leal et al. (2008) for several sites in Normandy. Special care must however be taken in the analysis of macroalgal contribution to the diet of oysters. To quantify the importance of macroalgae in the diet of oysters, we used the stable isotope ratios of fresh macroalgae as a proxy for detritus. Although decomposition can alter the isotopic composition of algae (Hill and McQuaid 2009), most studies have shown that this modification mostly affected nitrogen, in an unpredictable way, and that $\delta^{13} \mathrm{C}$ remained quite stable (Stephenson et al. 1986; Fenton and Ritz 1988; Schaal et al. 2010a). There is therefore of source of uncertainty in the actual contribution of macroalgae, because the effects of decomposition on the stable isotope ratios cannot be accurately determined. Macroalgal particles that are ingested by oysters are indeed microscopic, because oysters ingest particles within the $2 \mu \mathrm{m}-20 \mu \mathrm{m}$ range (Barillé et al. 1997), that cannot be efficiently sorted out of the pool of suspended material for isotopic analysis. We are however confident in the robustness of our diet estimations, because the strong correlation between $\delta^{15} \mathrm{~N}$ of oysters and biofilms (table 1) makes unlikely any dominance of macroalgae in the diet of oysters. Moreover, no correlation could be found between stable isotope ratios of oysters and macroalgae at the species level (data not shown). Finally, oysters have been proven to be capable of substantial selectivity when faced a composite pool of organic matter (Harris et al. 2010). Fresh particles (e.g. 
phytoplankton, benthic diatoms) are known to be of better nutritive value for consumers than decayed macroalgal particles (Hughes and Sherr 1983). It is therefore quite unlikely that macroalgae would make the major part of their diet in an environment where other sources (i.e. microalgae of benthic and pelagic origins) are present and abundant. Based on a single time study, we can hardly integrate our conclusions to a temporal perspective. Some of the patterns found here can indeed be quite seasonal (consumption of macroalgae, low phytoplankton contribution).The consumption of macroalgae has for example been reported to be especially important for suspension-feeders during periods of low phytoplankton productivity (Marin-Leal et al. 2008; Grippo et al. 2010). Moreover, our sampling was performed in winter, which does correspond to the lowest abundances of phytoplankton (Chauvaud et al. 2001). Complementary seasonal sampling, in particular during spring, when phytoplankton biomass is maximal, would help understand the seasonal dynamics of oysters trophic ecology along this estuarine gradient. Our study nevertheless depicts benthic biofilm as a key component of the trophic functioning of intertidal rocky shore associated suspension feeders during autumn in the Bay of Brest.

\subsection{Atypical stations: witnesses of anthropogenic influence?}

Unexpectedly ${ }^{13} \mathrm{C}$ depleted values were obtained for oysters at stations 5 and 6 (middle estuary). The estimation of oysters diet for these stations indicated homogeneous contribution of biofilm, marine POM and macroalgae (Fig. 5). Although most of the Elorn river southern bank is uninhabitated, small groups of houses are located at the vicinity of these two sampling stations (personal observation). Surveys have shown that this area is characterized by high bacteria (E. coli) concentrations (up to 2000 cells/100ml (IDHESA 2011)) which is much higher than what can be found elsewhere. It could be explained by the lack of connection to sewage treatment plants of most of buildings around there (BMO, city water treatment unit). Bacteria can display extremely wide ranges of $\delta^{13} \mathrm{C}$ (Coffin et al. 1989), which might explain the differences observed between these two stations and the other ones. Indeed, the consumption of bacteria by oysters has recently been supported by fatty acid data by Pernet et al. (2012).

\subsection{Conclusions}

Our results fit a commonly observed pattern of trophic functioning for temperate coastal ecosystems; benthic sources represent the major part of the diet of suspension-feeders (Riera and Richard 1996; Page and Lastra 2003; Schaal et al. 2008). The contribution of phytoplankton was low (typically less than $20 \%$ ), even on open sea sites. Overall, the diet of Crassostrea gigas did not vary much along the gradient, the main difference being the contribution of macroalgae detritus. Although oysters are known to be able to select among the different available food sources (Harris et al. 2010), this relative consistency suggests that the availability of food sources remains quite constant all along the gradient, and emphasizes the paramount importance of epilithic benthic biofilms for the general functioning of rocky shores in the Bay of Brest. The stability of SPOM composition along the gradient is furthermore confirmed by SIAR runs carried out to estimate the contribution of TPOM, MPOM, macroalgae and benthic biofilms along the gradient (suppl. material). Some studies, carried out on cultured oysters, have found contrasted results, phytoplankton being the most important contributor to the diet of oysters (Riera 2007; Lefebvre et al. 2009b). A possible explanation would be that cultivated oysters are usually reared on tables around $1 \mathrm{~m}$ above the sediment, which can potentially limit the availability of benthic sources, while wild oysters are directly in contact with the substrate, and can therefore readily ingest resuspended sources. Other factors, such as the topology of the coastline (open marine environments vs coastal 
embayments) have also been proven to affect the reliance of oysters toward benthic vs pelagic sources (Lefebvre et al. 2009b). Special care must therefore be taken before extending the conclusions of this study to other coastal ecosystems.

A good marker of ecosystem functioning must integrate the spatial and temporal variability that occurs naturally as well as be sensitive enough not to buffer small scale variability. In a recent study, Lefebvre et al. (2009a) suggested that cultivated oysters could be reliable indicators of ecosystem functioning, because, as sessile consumers, they are subject to the variations in quality and quantity of the suspended organic matter pool, and reflect local differences in the availability of the different food sources. In fact, several studies have used cultivated oysters in the past to infer ecosystem functioning (Piola et al. 2006; Marin-Leal et al. 2008; Lefebvre et al. 2009b), and few have used wild oysters (but see (Riera and Richard 1996; Fertig et al. 2009)). Our results suggest that wild oysters might better reflect benthic processes than cultivated, because their reliance toward benthic sources seems to be higher, due to closer relationship with the substrate.

In macrotidal ecosystems, strong tidal currents result in spatial homogenization of waters, and it could be expected that suspension feeders' stable isotope ratios would provide few information on small scale variability of ecosystem functioning. Our results show that this is not the case and that even at relatively small scale, the use of oysters allows identifying different geographical entities, and localized anthropogenic disturbances. Because, as revealed in our results, oysters in the Bay of Brest mainly feed on benthic sources (i.e. epilithic benthic biofilms and macroalgae), they reflect local processes occurring in the different rocky shore zones of the Bay, making them particularly relevant as functional typology indicators.

In the present study, we only analyzed adductor muscles, which proved to be suitable to reflect the variability of ecological processes occurring along this gradient. Due to the longer integration time of muscles, they can however buffer the effect of episodic nutrient pulses, that can be frequent and have strong effects in estuarine systems (Antonio et al. 2010). Using different tissues, such as gills or digestive glands, which have shorter integration times, would help characterize small scale temporal variability, and be of particular interest for highly dynamic systems such as estuaries (Piola et al. 2006).

\section{Acknowledgements}

The project was supported by the INSU EC2CO program ISOBENT and by the GIS- Europole Mer. We thank J-M. Munaron, E. Morize, E. Dabas, C. Oudard and A. Aguirre Velarde for their help in oyster sampling and preparation. We also thank E. Moreau-Haug of IDHESA Bretagne Oceane for providing a model of bacteria concentrations. We would like to thank the two anonymous reviewers for their helpful comments.

\section{References}

Alunno-Bruscia, M., Y. Bourlès, D. Maurer, S. Robert, J. Mazurié, A. Gangnery, P. Goulletquer and S. Pouvreau. 2011. A single bio-energetics growth and reproduction model for the oyster Crassostrea gigas in six Atlantic ecosystems. Journal of sea research 66: 340-348.

Antonio, E. S., A. Kasai, M. Ueno, N. Won, Y. Ishihi, H. Yokoyama and Y. Yamashita. 2010. Spatial variation in organic matter utilization by benthic communities from Yura River-Estuary to offshore of Tango Sea, Japan. Estuarine Coastal and Shelf Science 86: 107-117. 
Barillé, L., J. Prou, M. Héral and D. Razet. 1997. Effects of high natural seston concentrations on the feeding, selection, and absorption of the oyster Crassostrea gigas (Thunberg). Journal of experimental marine biology and ecology 212: 149-172.

Bretagne environnement. 2009. FICHE DE SYNTHESE - Concentrations en nitrates. www.bretagneenvironnement.org/content/.../Rade-Elorn-29.pdf.Accessed 23 May 2012.

Chauvaud, L., A. Donval, G. Thouzeau, Y. M. Paulet and E. Nézan. 2001. Variations in food intake of Pecten maximus (L.) from the Bay of Brest (France): Influence of environnemental factors and phytoplankton species composition. . Life sciences 324: 743-755.

Coffin, R. B., B. Fry, B. J. Peterson and R. T. Wright. 1989. Carbon isotopic compositions of estuarine bacteria. Limnology and Oceanography: 1305-1310.

Costanzo, S. D., M. J. O'Donohue, W. C. Dennison, N. R. Loneragan and M. Thomas. 2001. A new approach for detecting and mapping sewage impacts. Marine Pollution Bulletin 42: 149-156.

Currin, C. A., S. Y. Newell and H. W. Paerl. 1995. The role of standing dead Spartina alterniflora and benthic microalgae in salt-marsh food webs: considerations based on pultiple stable isotope analysis. Marine EcologyProgress Series 121: 99-116.

Deegan, L. A. and R. H. Garritt. 1997. Evidence for spatial variability in estuarine food webs. Marine ecology progress series Oldendorf 147: 31-47.

Dubois, S., B. Jean-Louis, B. Bertrand and S. Lefebvre. 2007a. Isotope trophic-step fractionation of suspension-feeding species: Implications for food partitioning in coastal ecosystems. Journal of experimental marine biology and ecology 351: 121-128.

Dubois, S., F. Orvain, J. C. Marin-Leal, M. Ropert and S. Lefebvre. 2007b. Small-scale spatial variability of food partitioning between cultivated oysters and associated suspension-feeding species, as revealed by stable isotopes. Marine Ecology Progress Series 336: 151-160.

Fenton, G. E. and D. A. Ritz. 1988. Changes in carbon and hydrogen stable isotope ratios of macroalgae and seagrass during decomposition. Estuarine, Coastal and Shelf Science 26: 429-436.

Fertig, B., T. J. B. Carruthers, W. Dennison, A. Jones, F. Pantus and B. Longstaff. 2009. Oyster and Macroalgae Bioindicators Detect Elevated $\delta 15 \mathrm{~N}$ in Maryland's Coastal Bays. Estuaries and Coasts 32: 773-786.

Fertig, B., T. J. B. Carruthers, W. C. Dennison, E. J. Fertig and M. A. Altabet. 2010. Eastern oyster (Crassostrea virginica) delta N-15 as a bioindicator of nitrogen sources: Observations and modeling. Marine Pollution Bulletin 60: 1288-1298.

Grall, J., L. Chauvaud, G. Thouzeau, S. Fifas, M. Glemarec and Y. M. Paulet. 1996. Distribution de Pecten maximus (L.) et de ses principaux compétiteurs et prédateurs potentiels en rade de Brest. Comptes rendus de l'Académie des sciences Série 3, Sciences de la vie 319: 931-937.

Grall, J. and M. Glémarec. 1997. Using biotic indices to estimate macrobenthic community perturbations in the Bay of Brest. Estuarine, Coastal and Shelf Science 44: 43-53.

Grippo, M. A., J. W. Fleeger, N. N. Rabalais, R. Condrey and K. R. Carman. 2010. Contribution of phytoplankton and benthic microalgae to inner shelf sediments of the north-central Gulf of Mexico. Continental Shelf Research 30: $456-466$ 
Harris, J. K., J. W. Sahl, T. A. Castoe, B. D. Wagner, D. D. Pollock and J. R. Spear. 2010. Comparison of normalization methods for construction of large, multiplex amplicon pools for next-generation sequencing. Applied and environmental microbiology 76: 3863-3868.

Hawkins, S., D. Watson, A. Hill, S. Harding, M. Kyriakides, S. Hutchinson and T. Norton. 1989. A comparison of feeding mechanisms in microphagous, herbivorous, intertidal, prosobranchs in relation to resource partitioning. Journal of Molluscan Studies 55: 151-165.

Hill, J. M. and C. D. McQuaid. 2009. Variability in the fractionation of stable isotopes during degradation of two intertidal red algae. Estuarine, Coastal and Shelf Science 82: 397-405.

Hughes, E. H. and E. B. Sherr. 1983. Subtidal food webs in a georgia estuary: $\delta^{13} \mathrm{C}$ analysis. Journal of experimental marine biology and ecology 67: 227-242.

IDHESA.2011. Plage du Passage, commune du Relecq-Kerhuon Finistère, profil des eaux de baignades. In. IDHESA Brest métropole océane, Brest

Kang, C., P. Sauriau, P. Richard and G. Blanchard. 1999. Food sources of the infaunal suspension-feeding bivalve Cerastoderma edule in a muddy sandflat of Marennes-Oléron Bay, as determined by analyses of carbon and nitrogen stable isotopes. Marine Ecology Progress Series 187: 147-158.1999.

Le Berre, I., C. Hily, M. Lejart and R. Gouill. 2009. Analyse spatiale de la prolifération de C. gigas en Bretagne. http://cybergeo.revues.org/22818. Accessed 07 mai 2012.

Le Pape, O. 1996. Modélisation des cycles biogéochimiques des éléments limitant la production phytoplanctonique en rade de Brest. Thesis. Ecole nationale supérieure d'agronomie de Rennes, Rennes.

Le Pape, O., Y. Del Amo, A. Menesguen, A. Aminot, B. Quequiner and P. Treguer. 1996. Resistance of a coastal ecosystem to increasing eutrophic conditions: the Bay of Brest (France), a semi-enclosed zone of Western Europe. Continental Shelf Research 16: 1885-1907.

Lefebvre, S., C. Harma and J. L. Blin. 2009a. Trophic typology of coastal ecosystems based on delta C-13 and delta N15 ratios in an opportunistic suspension feeder. Marine Ecology Progress Series 390: 27-37.

Lefebvre, S., J. C. M. Leal, S. Dubois, F. Orvain, J. L. Blin, M. P. Bataille, A. Ourry and R. Galois. 2009b. Seasonal dynamics of trophic relationships among co-occurring suspension-feeders in two shellfish culture dominated ecosystems. Estuarine Coastal and Shelf Science 82: 415-425.

Lejart, M. 2009. Etude du processus invasif de Crassostrea gigas en Bretagne: Etat des lieux, dynamique et conséquences écologiques. Thesis. Université de Bretagne occidentale, Brest.

Lorrain, A., Y. M. Paulet, L. Chauvaud, N. Savoye, A. Donval and C. Saout. 2002. Differential delta C-13 and delta N15 signatures among scallop tissues: implications for ecology and physiology. Journal of experimental marine biology and ecology 275: 47-61.

Lorrain, A., N. Savoye, L. Chauvaud, Y. M. Paulet and N. Naulet. 2003. Decarbonation and preservation method for the analysis of organic $\mathrm{C}$ and $\mathrm{N}$ contents and stable isotope ratios of low-carbonated suspended particulate material. Analytica Chimica Acta 491: 125-133.

Malet, N. 2005. Ecologie alimentaire de l'huitre Crassostrea gigas : dynamiques des compositions isotopiques naturelles. Thesis. Université de La Rochelle, La Rochelle.

Mann, K. H. 1982 Ecology of coastal waters. A Systems Approach, Vol 8. University of California press, Berkeley and Los Angeles 
Marin-Leal, J. C., S. Dubois, F. Orvain, R. Galois, J. L. Blin, M. Ropert, M. P. Bataille, A. Ourry and S. Lefebvre. 2008. Stable isotopes (delta C-13, delta $\mathrm{N}-15$ ) and modelling as tools to estimate the trophic ecology of cultivated oysters in two contrasting environments. Marine Biology 153: 673-688.

McCutchan, J. H., W. M. Lewis, C. Kendall and C. C. McGrath. 2003. Variation in trophic shift for stable isotope ratios of carbon, nitrogen, and sulfur. OIKOS 102: 378-390.

Nérot, C. 2011. Invertébrés benthiques et biomarqueurs : témoins du fonctionnement trophique des écosystèmes côtiers. Thesis., Brest.

Page, H. and M. Lastra. 2003. Diet of intertidal bivalves in the Ria de Arosa (NW Spain): evidence from stable C and N isotope analysis. Marine Biology 143: 519-532.

Parnell, A. C., R. Inger, S. Bearhop and A. L. Jackson. 2010. Source partitioning using stable isotopes: coping with too much variation. PloS one 5: e9672.

Pernet, F., N. Malet, A. Pastoureaud, A. Vaguer, C. Quere and L. Dubroca. 2012. Marine diatoms sustain growth of bivalves in a Mediterranean lagoon. Journal of sea research 68: 20-32.

Peterson, B. J. and B. Fry. 1987. Stable isotopes in ecosystem studies. Annual review of ecology and systematics 18: 293-320.

Phillips, D. L. and J. W. Gregg. 2003. Source partitioning using stable isotopes: coping with too many sources. Oecologia 136: 261-269.

Piola, R. F., S. K. Moore and I. M. Suthers. 2006. Carbon and nitrogen stable isotope analysis of three types of oyster tissue in an impacted estuary. Estuarine, Coastal and Shelf Science 66: 255-266.

Post, D. M. 2002. Using stable isotopes to estimate trophic position: models, methods, and assumptions. Ecology 83: 703-718.

R development Core Team.2005. R : a language and environment for statistical computing. In, R Foundation for Statistical Computing, Vienna, Austria

Rajagopal, M. D. 1997. Some Aspects on the Interrelationships between Nutrients and Plankton in the Estuarine and Nearshore Regions of Goa. Thesis. Cochin University of Science and Technology, Cochin.

Riera, P. 1998. delta N-15 of organic matter sources and benthic invertebrates along an estuarine gradient in MarennesOleron bay (France): implications for the study of trophic structure. Marine Ecology Progress Series 166: 143150.

Riera, P. 2007. Trophic subsidies of Crassostrea gigas, Mytilus edulis and Crepidula fornicata in the Bay of Mont Saint Michel (France): $\mathrm{A} \delta^{13} \mathrm{C}$ and $\delta^{15} \mathrm{~N}$ investigation. Estuarine, Coastal and Shelf Science 72: 33-41.

Riera, P. 2009. Trophic plasticity in similar habitats: an example which severely limits generalization among ecosystems. Marine Biodiversity Records 2: e47.

Riera, P. and P. Richard. 1996. Isotopic Determination of Food Sources of Crassostrea gigas along a Trophic Gradient in the Estuarine Bay of Marennes-Oléron. Estuarine, Coastal and Shelf Science 42: 347-360.

Riera, P., L. J. Stal and J. Nieuwenhuize. 2000. Heavy d15N in Intertidal Benthic Algae and Invertebrates in the Scheldt Estuary (The Netherlands): Effect of River Nitrogen Inputs. Estuarine, Coastal and Shelf Science 51: 365-372.

Savoye, N. 2001. Origine et transfert de la matière organique particulaire dans les écosystèmes littoraux macrotidaux. Thesis. Université de Bretagne Occidentale, Brest.

Schaal, G., P. Riera and C. Leroux. 2008. Trophic coupling between two adjacent benthic food webs within a manmade intertidal area: A stable isotopes evidence. Estuarine, Coastal and Shelf Science 77: 523-534. 
Schaal, G., P. Riera and C. Leroux. 2010a. Trophic ecology in a Northern Brittany (Batz Island, France) kelp (Laminaria digitata) forest, as investigated through stable isotopes and chemical assays. Journal of sea research 63: 24-35.

Schaal, G., P. Riera, C. Leroux and J. Grall. 2010b. A seasonal stable isotope survey of the food web associated to a peri-urban rocky shore. Marine Biology 157: 283-294.

Stephenson, R., F. Tan and K. Mann. 1986. Use of stable carbon isotope ratios to compare plant material and potential consumers in a seagrass bed and a kelp bed in Nova Scotia, Canada. Mar Ecol Prog Ser 30: 1-7.

Takai, N., A. Yorozu, T. Tanimoto, A. Hoshika and K. Yoshihara. 2004. Transport pathways of microphytobenthosoriginating organic carbon in the food web of an exposed hard bottom shore in the Seto Inland Sea, Japan. Marine Ecology Progress Series 284: 97-108.

Vander Zanden, M. J. and J. B. Rasmussen. 2001. Variation in 15N and 13C trophic fractionation: implications for aquatic food web studies. Limnology and Oceanography: 2061-2066.

Yokoyama, H., Y. Ishihi and S. Yamamoto. 2008. Diet-tissue isotopic fractionation of the Pacific oyster Crassostrea gigas. Marine Ecology Progress Series 358: 173-179.

York, J. K., G. Tomasky, I. Valiela and D. J. Repeta. 2007. Stable isotopic detection of ammonium and nitrate assimilation by phytoplankton in the Waquoit Bay estuarine system. Limnology and Oceanography 52: 144155. 
Table 1 Linear regressions between stable isotope ratios of oyster muscles and food sources. n=19 for each regression

\begin{tabular}{|c|c|c|c|c|c|c|}
\hline \multirow{2}{*}{ Sources } & & \multicolumn{2}{|c|}{$\delta^{13} \mathrm{C}$ of oyster } & & \multicolumn{2}{|c|}{$\delta^{15} \mathrm{~N}$ of oyster } \\
\hline & & $\mathrm{R}^{2}$ & p-value & & $\overline{\mathrm{R}^{2}}$ & p-value \\
\hline biofilm & $\delta^{13} \mathrm{C}$ & 0.05 & 0.39 & $\delta^{15} \mathrm{~N}$ & 0.73 & $<0.01$ \\
\hline SPOM & $\delta^{13} \mathrm{C}$ & 0.01 & 0.34 & $\delta^{15} \mathrm{~N}$ & 0.02 & 0.61 \\
\hline macroalgae & $\delta^{13} \mathrm{C}$ & 0.03 & 0.48 & $\delta^{15} \mathrm{~N}$ & 0.01 & 0.86 \\
\hline
\end{tabular}


Table 2 Results of Kruskal-Wallis tests on food sources data and 7 groups of station. Bold values indicate significant differences

\begin{tabular}{lcc}
\hline \multicolumn{1}{c}{$\delta^{13} \mathrm{C}$} & $\mathrm{H}$ & $\mathrm{p}$-value \\
\hline Groups of station $* \delta^{13} \mathrm{C}$ of macroalgae & 2.3147 & 0.8886 \\
Groups of station $* \delta^{13} \mathrm{C}$ of biofilm & 5.2053 & 0.5178 \\
Groups of station $* \delta^{13} \mathrm{C}$ of POM & 28.4824 & $<\mathbf{0 . 0 1}$ \\
\hline \multicolumn{1}{c}{$\delta^{15} \mathrm{~N}$} & $\mathrm{H}$ & $\mathrm{p}$-value \\
\hline Groups of station $* \delta^{15} \mathrm{~N}$ of macroalgae & 23.3049 & $<\mathbf{0 . 0 1}$ \\
Groups of station $* \delta^{15} \mathrm{~N}$ of biofilm & 15.4833 & $<\mathbf{0 . 0 5}$ \\
Groups of station $* \delta^{15} \mathrm{~N}$ of POM & 11.6830 & 0.0694 \\
\hline
\end{tabular}


Table 3 Estimates of food sources contribution to oysters diet using different trophic-step fractionation values

\begin{tabular}{cccccc} 
& & \multicolumn{4}{c}{ Contribution (\%) } \\
\cline { 3 - 6 } groups & Ref. & Biofilm & MPOM & Macroalgae & TPOM \\
\hline \multirow{3}{*}{ Upstream estuary } & $(1)$ & 52 & 11 & 33 & 4 \\
& $(2)$ & 32 & 30 & 34 & 4 \\
& $(3)$ & 5 & 28 & 64 & 4 \\
\hline \multirow{3}{*}{ Middle estuary } & $(1)$ & 30 & 36 & 30 & 4 \\
& $(2)$ & 28 & 50 & 17 & 5 \\
Downstream estuary & $(3)$ & 36 & 28 & 29 & 7 \\
& $(1)$ & 60 & 25 & 13 & 2 \\
& $(2)$ & 45 & 47 & 6 & 2 \\
& $(3)$ & 52 & 20 & 25 & 3 \\
\hline \multirow{3}{*}{ Inner bay } & $(1)$ & 47 & 21 & 26 & 6 \\
& $(2)$ & 43 & 43 & 9 & 6 \\
& $(3)$ & 47 & 29 & 17 & 7 \\
\hline \multirow{2}{*}{ Channel } & $(1)$ & 86 & 4 & 9 & 1 \\
& $(2)$ & 79 & 16 & 3 & 2 \\
& $(3)$ & 85 & 5 & 8 & 2 \\
\hline \multirow{2}{*}{ Outside bay } & $(1)$ & 63 & 16 & 18 & 3 \\
& $(2)$ & 82 & 5 & 12 & 1 \\
& $(3)$ & 56 & 7 & 35 & 2 \\
\hline
\end{tabular}

\section{References :}

(1) Dubois et al. (2007a) : $\Delta \delta^{13} \mathrm{C}=1.9 \%$ et $\Delta \delta^{15} \mathrm{~N}=3.8 \%$

(2) Lefebvre et al. (2009a) : $\Delta \delta^{13} \mathrm{C}=2.9 \%$ et $\Delta \delta^{15} \mathrm{~N}=4.7 \%$

(3) fractionation values of Dubois et al. (2007a) modified by muscle to whole body fractionation ( $0.4 \%$ for $\Delta \delta^{13} \mathrm{C}$ and $3.3 \%$ for $\Delta \delta^{15} \mathrm{~N}$ ) of Yokoyama et al. (2008). $\Delta \delta^{13} \mathrm{C}=2.3 \%$ et $\Delta \delta^{15} \mathrm{~N}=7.1 \%$ 


\section{Figure legends}

Fig. 1 Localization of sampling stations along the estuarine gradient in the Bay of Brest $\left(48^{\circ} 10^{\prime}-48^{\circ} 25^{\prime} \mathrm{N}^{\prime} 4^{\circ} 10^{\prime}-\right.$ $\left.4^{\circ} 35^{\prime} \mathrm{W}\right)$. Station 1 was used as a reference to measure distances in the estuarine/open sea gradient

Fig. $2 \delta^{13} \mathrm{C}$ (upper panel) and $\delta^{15} \mathrm{~N}$ (lower panel) ( \pm sd) of oyster muscles at each station expressed in terms of distance to station 1

Fig. 3 Hierarchical clustering (Euclidean dissimilarity) based on stable isotope ratios $\left(\delta^{13} \mathrm{C}\right.$ and $\left.\delta^{15} \mathrm{~N}\right)$ of oysters muscles for the 19 stations. ANOSIM (analysis of similarities) indicated that the 7 groups are significantly different (R=0.896 and p-value $<0.001)$

Fig. $4 \delta^{13} \mathrm{C}$ (left) and $\delta^{15} \mathrm{~N}$ (right) ( \pm sd) of potential food sources (macroalgae, SPOM and biofilm) along the estuarine gradient

Fig. 5 Results of SIAR (Stable Isotope Analysis with R) oysters diet modeling along the estuarine gradient. Station 18 was excluded of this analysis because of the lack of sufficient data for this station. Confidence intervals are 95\% (in dark grey), 75\% (in medium gray) and 50\% (in light grey). MPOM=Marine Particular Organic Matter, TPOM=Terrestrial Particular Organic Matter (see section “data analysis” in material and methods for more details on how values were calculated) 
Figure 1

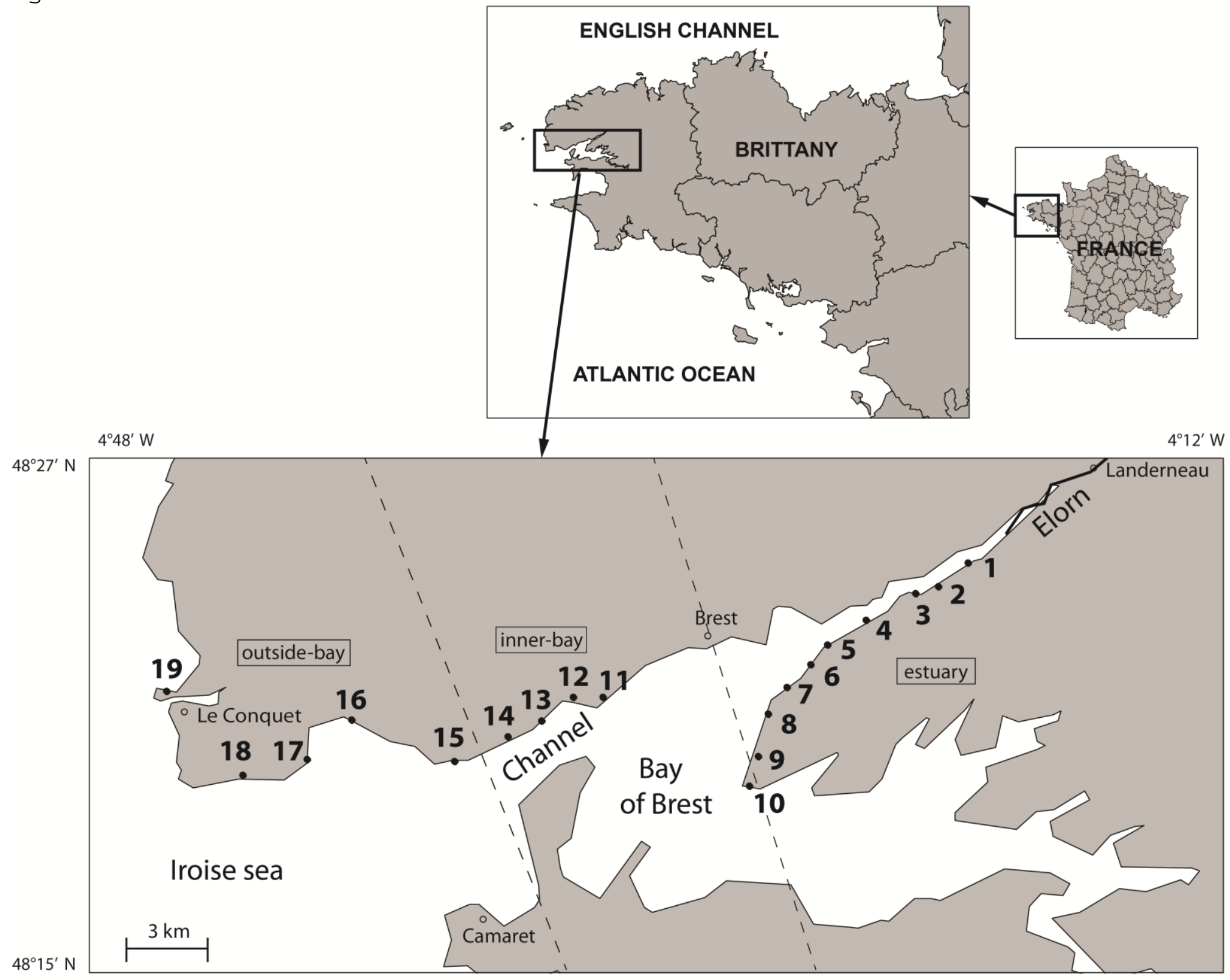



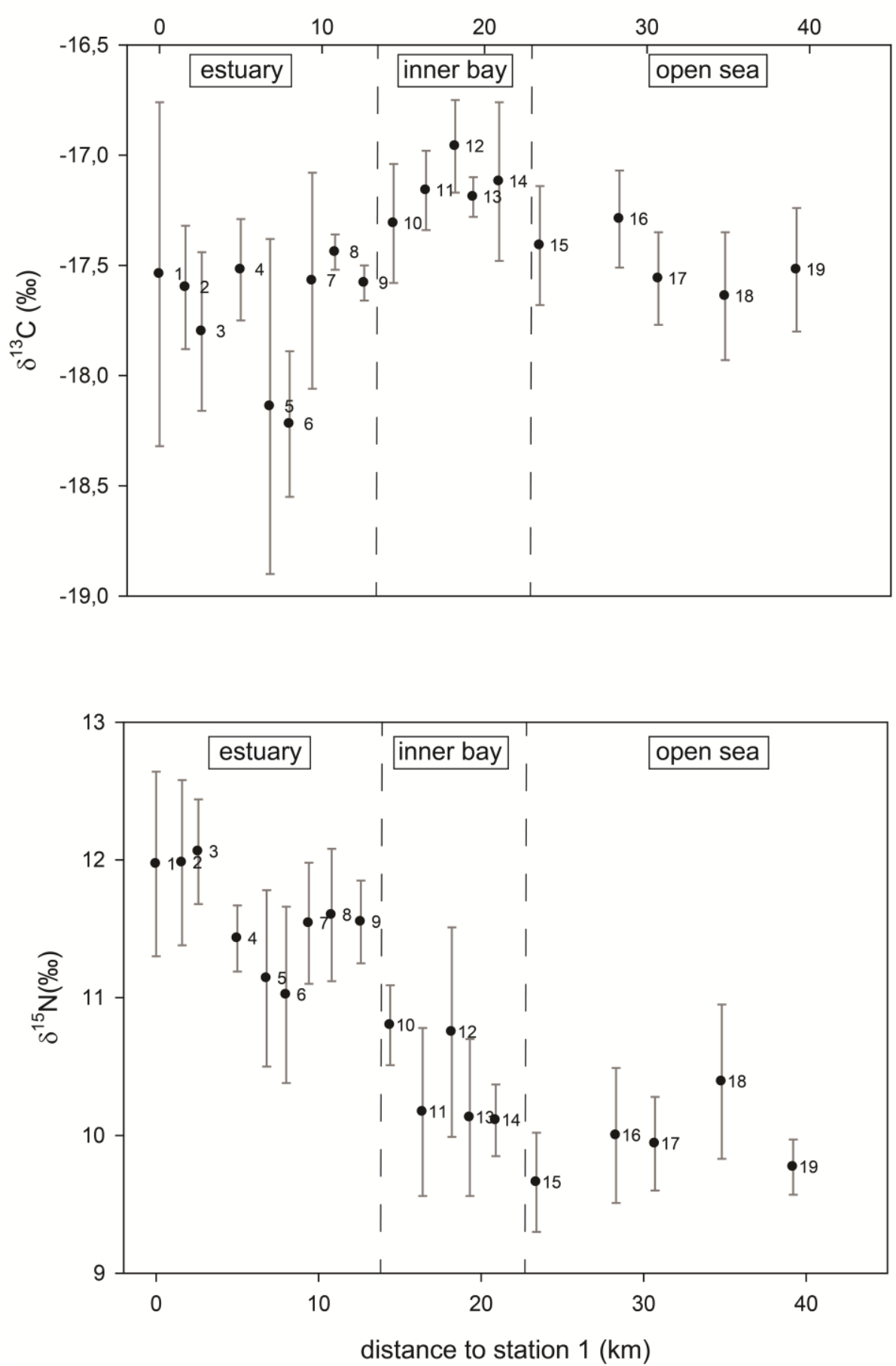


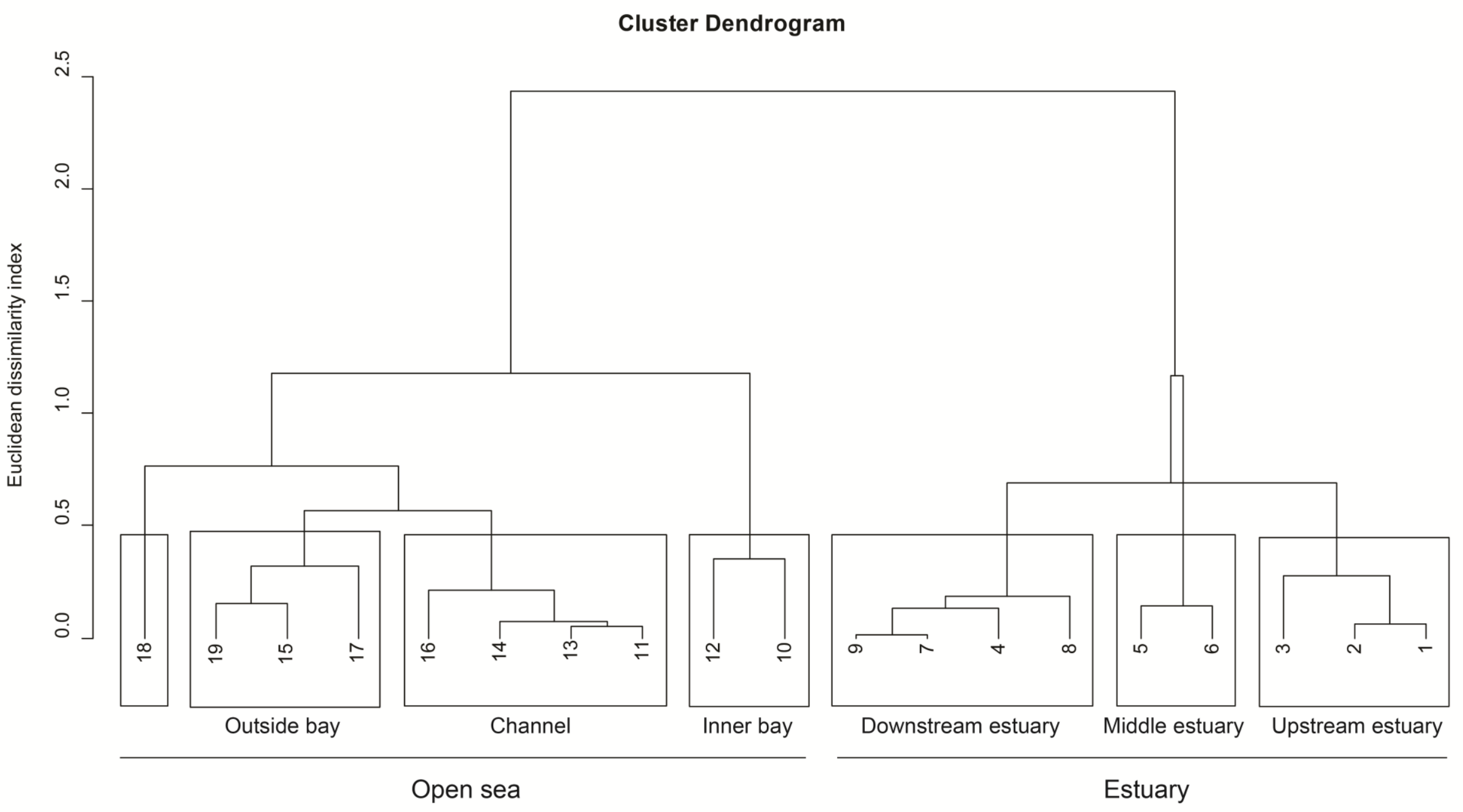




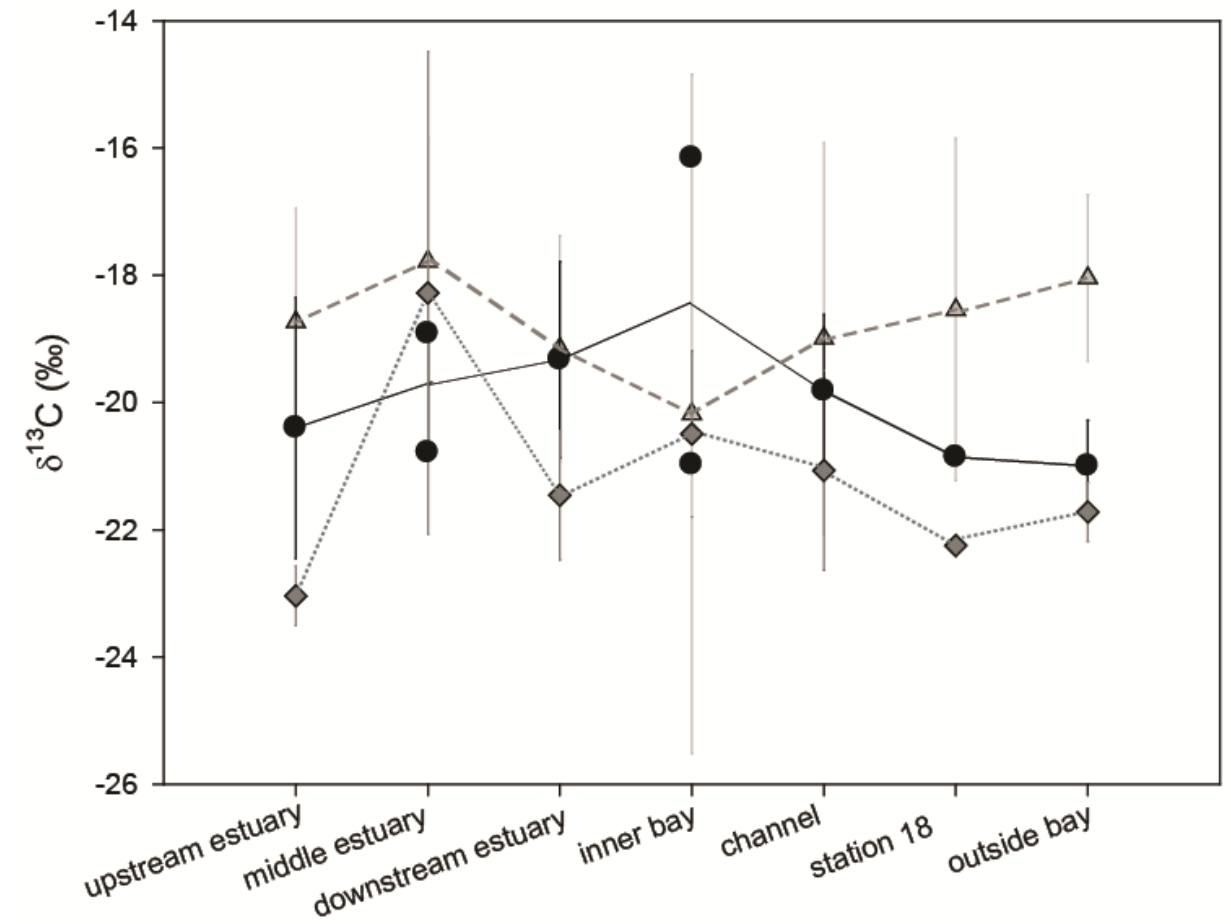

station's groups

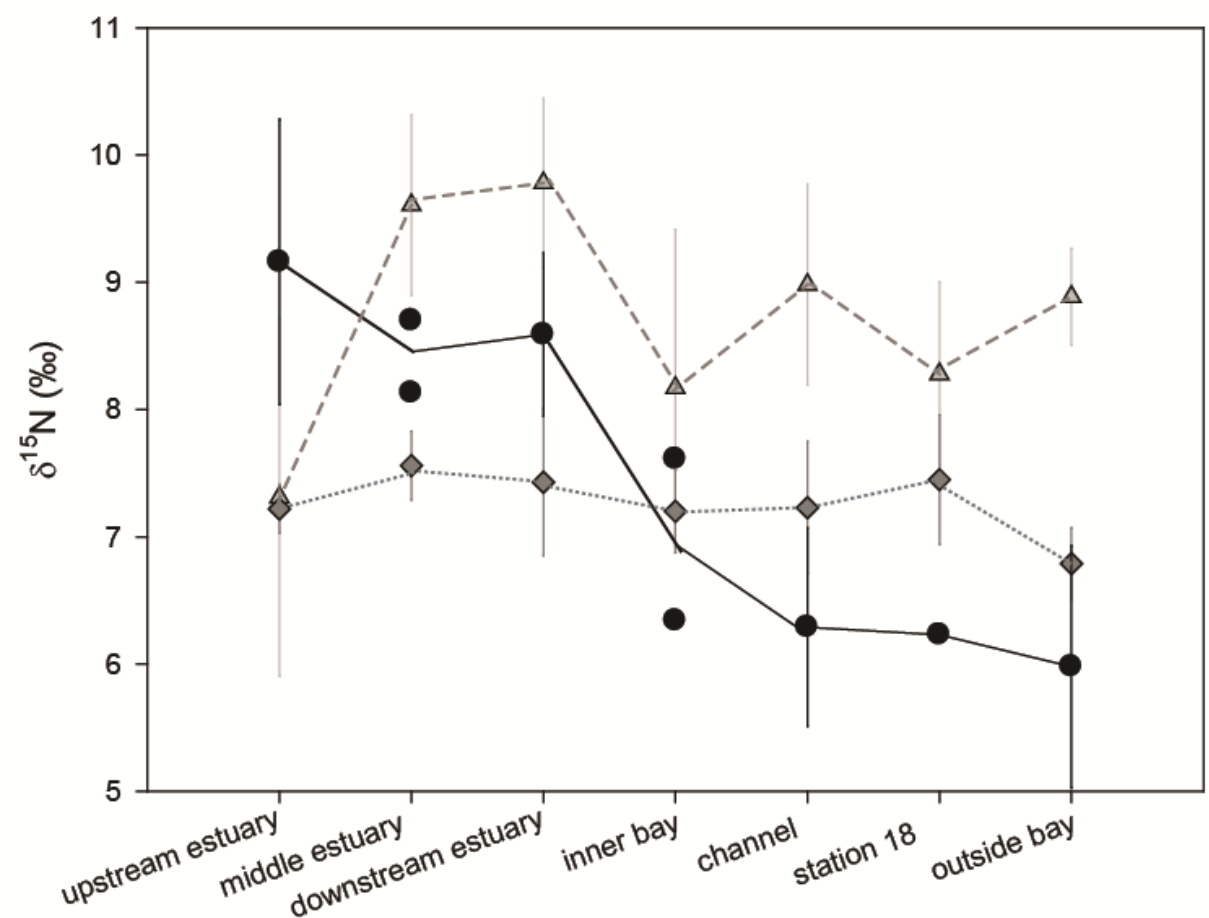

station's groups

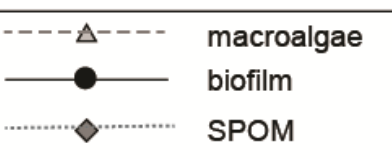


Figure $5 \quad$ Upstream estuary

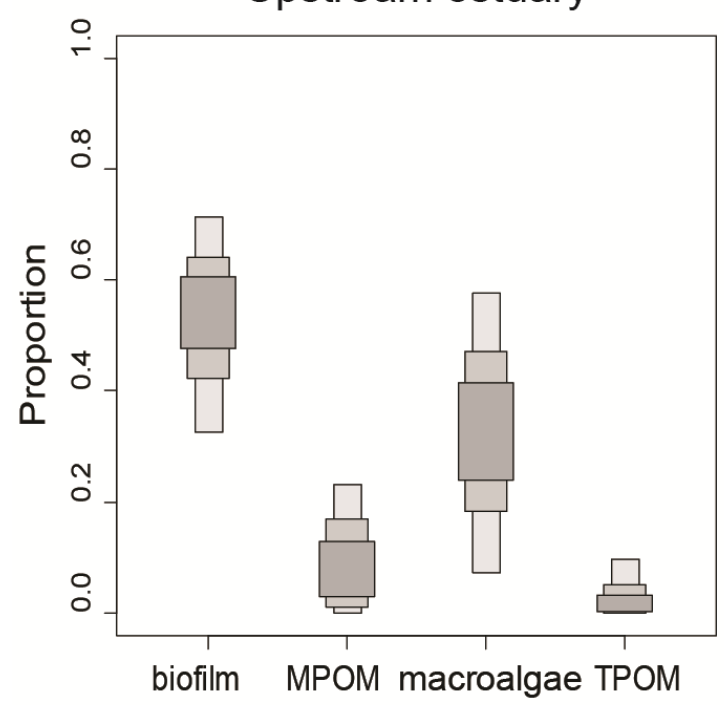

Sources

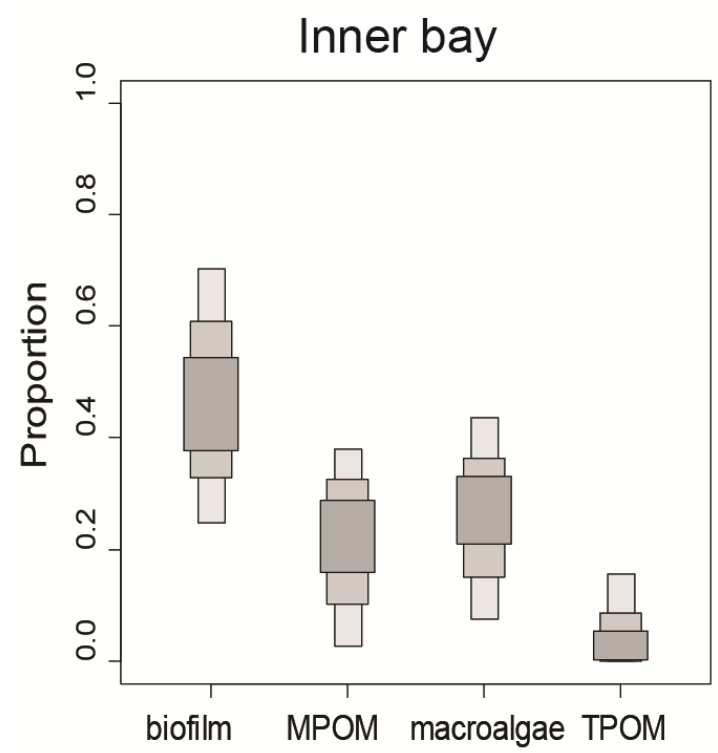

Sources

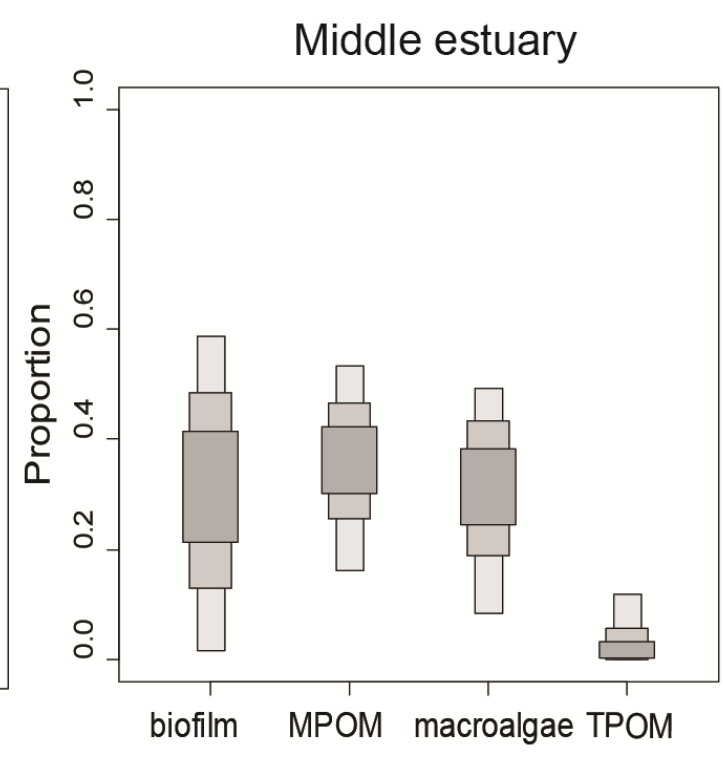

Sources

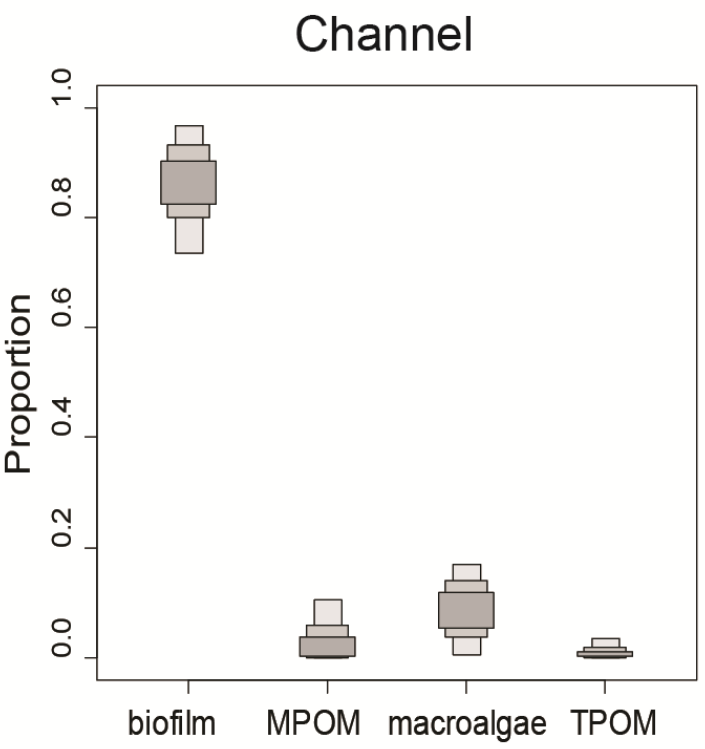

Sources

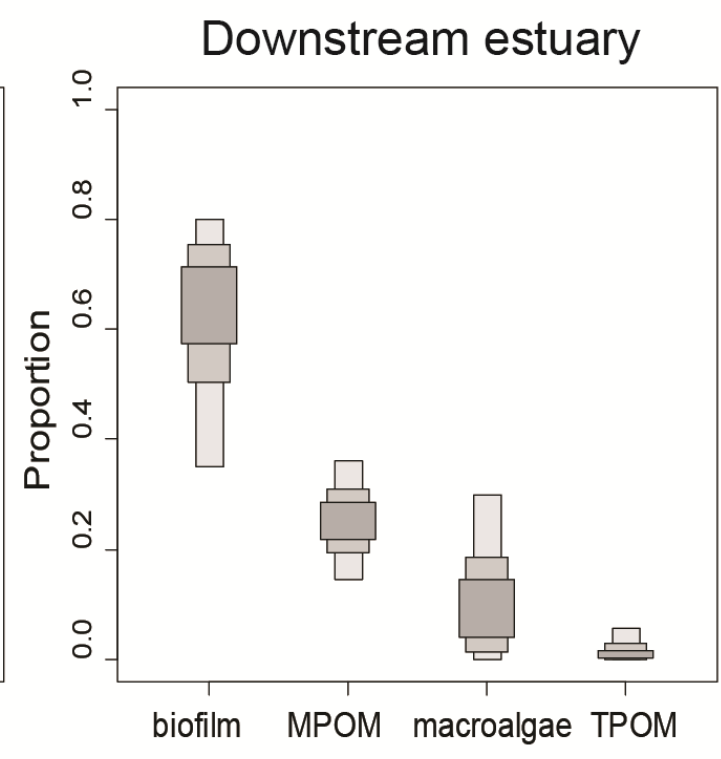

Sources

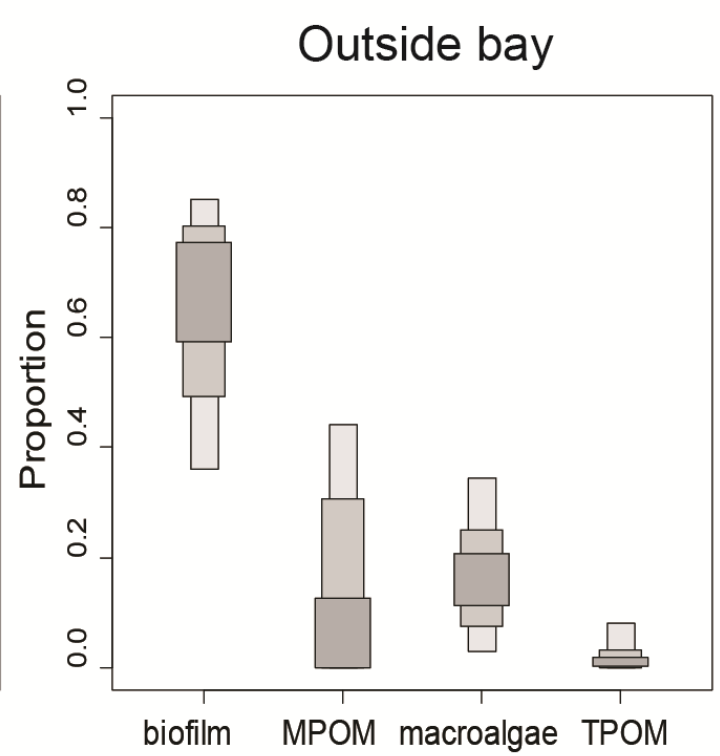

Sources 